\title{
Beef cattle housing and handling techniques in Mubi, Adamawa State, Nigeria
}

${ }^{1}$ Kubkomawa, H. I. ${ }^{2}$ Kenneth-Chukwu, A. M., ${ }^{3}$ Krumah, J. L., ${ }^{3}$ Yerima, I. N., ${ }^{4}$ Audu, Z. and ${ }^{4}$ Nafarnda, W. D.

${ }^{\prime}$ Department of Fisheries Technology, Federal Polytechnic, Mubi Adamawa State, Nigeria

${ }^{2}$ Department of Veterinary Biochemistry and Animal Production, College of Veterinary Medicine, Micheal Okpara University of Agriculture, Umudike, Abia State, Nigeria

${ }^{3}$ Department of Animal Health and Production Technology, Adamawa State College of Agriculture, Ganye

${ }^{4}$ Faculty of Veterinary Medicine, University of Abuja, Nigeria

Corresponding author: kubkomawa@yahoo.com; 07066996221

\section{Abstract}

The objective of the study was to survey beef cattle housing and handling techniques in Mubi, Adamawa State, Nigeria in order to make room for improvement to ensure their welfare. One hundred (100) beef producers were randomly selected for oral interviews, discussion and physical observations on beef cattle housing and handling techniques. This was achieved by the use of structured questionnaire for the period of 12 months (January to December, 2018). All beef cattle producers (100\%) use make shift kraals or fenced yards without roofs, while $90 \%$ use local handling equipment for the business in the study area. The use of elaborate housing and conventional equipment is limited in the study area. Though producers know that, well designed and maintained handling facilities are essential for the safe handling of beef cattle and prevention of injury to handlers. Good cattle handling facilities provide high level of control and safe access for the various husbandry tasks. Many accidents involving cattle could be eliminated with better handling facilities. Knowing the correct procedure is important for both the animals and handlers as handlers are susceptible to injuries.

Keywords: Beef Cattle Housing, Handling Techniques, Mubi, Adamawa State, Nigeria

\section{Introduction}

Beef cattle do not require elaborate housing, especially if they are grazed on pasture during the rainy season (Alberta, 2014). The primary purpose of housing is to provide shelter from extreme weather conditions. However, cattle can be kept outside if they have protection from the weather.

Cattle are large and strong animals that can behave unpredictably, especially when they are not used to handling. It is paramount to always bear this in mind, and to take all possible precautions to ensure safety of the operators. In beef cattle production, management of animals involves housing, dipping, hand dressing, vaccination, branding, weighing, dehorning, castration, earmarking, pregnancy testing, drafting, and treatment of sick ones (Adamu and Kubkomawa, 2018). All these management practices require that cattle be touched for at least about 50 times per annum thus the need for them to be properly. The objective of the study was to survey beef cattle housing and handling techniques in Mubi, Adamawa State, Nigeria in order to make room for improvement to ensure their welfare.

\section{Materials and method \\ The study area}

Adamawa State is located at the area where the River Benue enters Nigeria from Cameroon Republic and is one of the six states in the North-East geopolitical zone of 
Nigeria. It lies between latitudes $7^{\circ}$ and $11^{\circ}$ North of the Equator and between longitudes $11^{\circ}$ and $14^{\circ}$ East of the Greenwich Meridian (Mohammed, 1999). It shares an international boundary with the Republic of
Cameroon to the East and interstate boundaries with Borno to the North, Gombe to the North-West and Taraba to the South- West (ASMLS, 2010), as shown in Figures 1.

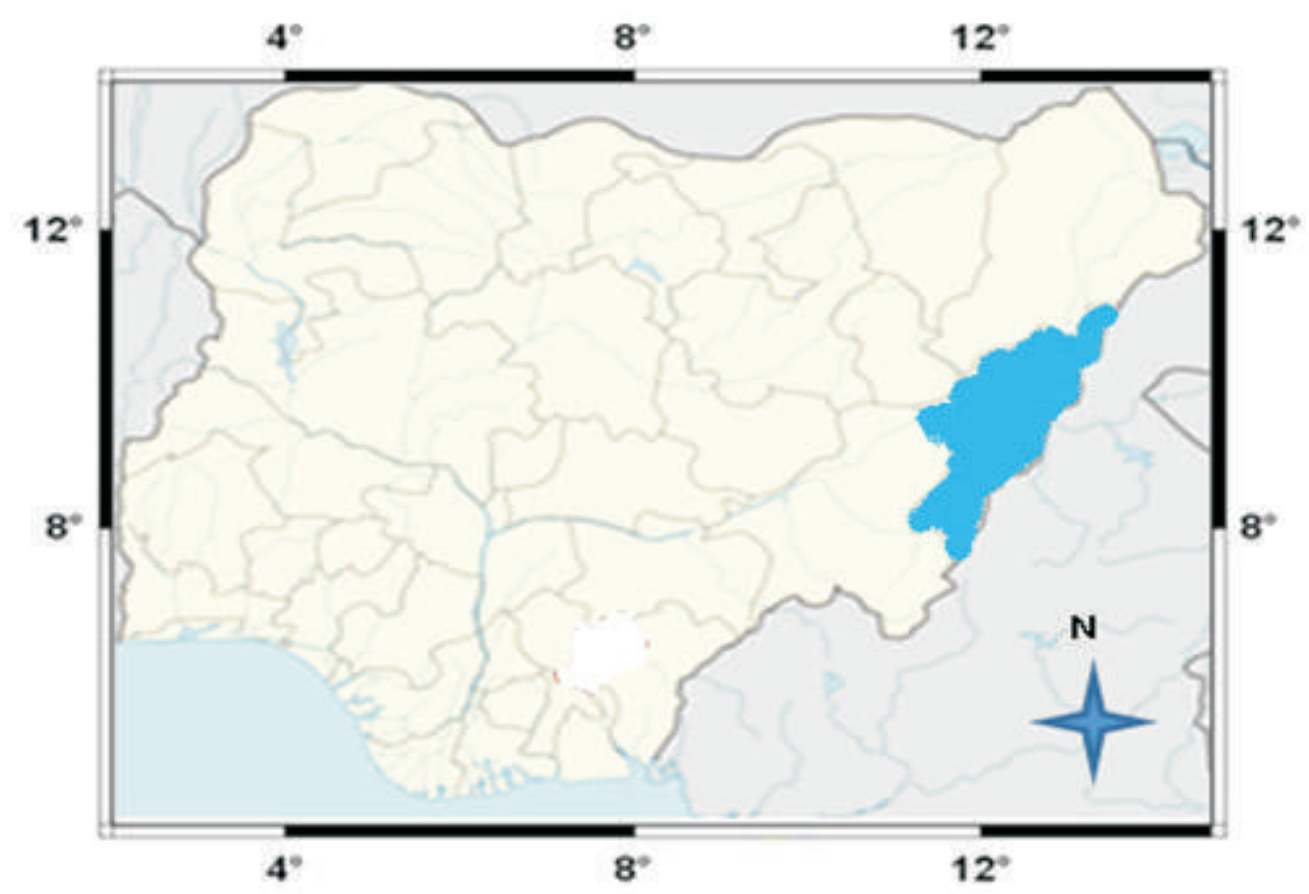

Figure 1: The Map of Nigeria Showing Adamawa State

\section{The study site}

Mubi is located at the Northern part of old Sardauna Province, which now forms Adamawa North Senatorial district as defined by INEC (1996) as shown in Figure 2. The region lies between latitude $9^{\circ} 30^{\prime \prime}$ and $11^{\circ}$ North of the Equator and longitude $13^{\circ}$ and $13^{\circ} 45^{\prime \prime}$ East of Greenwich Meridian. It has an altitude of 696 meters above sea level with an annual mean rainfall of $1,220 \mathrm{~mm}$ and a mean temperature of $15.2^{\circ} \mathrm{C}$ during Hamattan periods from November to February and $39.7^{\circ} \mathrm{C}$ in April (ADADP, 1986). The town essentially has a mountainous landscape transversed by River Yedzaram and many tributaries.
Mandara and Adamawa Mountains form part of this undulating Landscape (Mansir, 2006). The Gude, Fali, Fulani and other tribes dominate the area which has a lot of pasture land. Mubi region is bordered in the North by Borno State, in the West by Hong and Song LGAs and in the South and East by the Republic of Cameroon. It has a land area of about $4,728.77 \mathrm{~km}^{2}$ and human population of about 759,045 , going by NPC, (1991) census projected figure (Adebayo, and Tukur, 1991). It has an international cattle market linking neighboring and other countries such as Cameroon, Chad, Central Africa, Niger, Mali and Senegal to Southern Nigeria where cattle are consumed. 


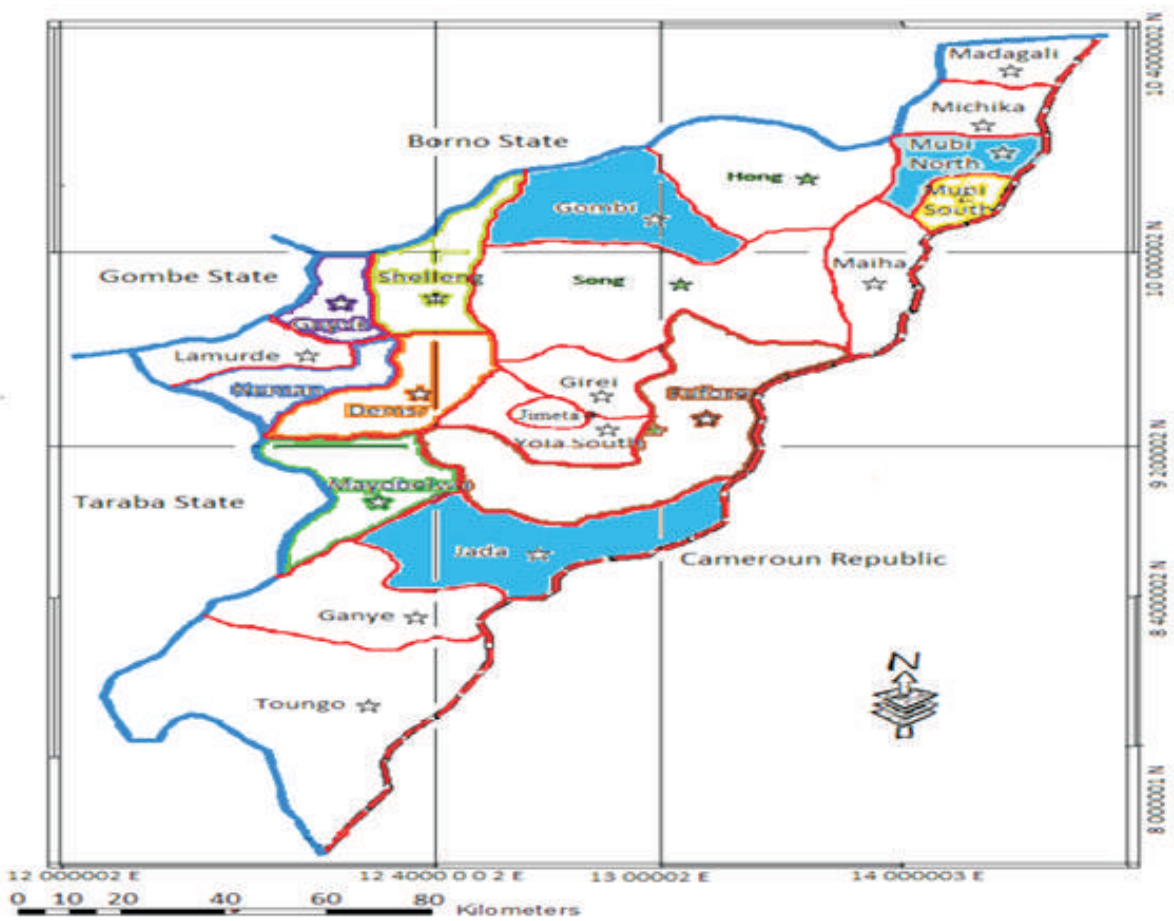

Figure 2: The map of Adamawa State showing the study location in blue and yellow colours

\section{Selection of respondents and sampling design Data analysis}

The research covered a period of 12 months (January to December, 2018), during the survey, visits were paid to beef fattening sites, government institutions, abattoir and Mubi international livestock market where respondents were identified. The objective of the study was explained to them and their permission obtained to participate in the study. Actual participation in the study was based on the willingness of respondents.

\section{Data collection}

One hundred (100) beef producers were randomly selected for oral interviews, discussion and physical observations on beef cattle housing and handling techniques. Structured questionnaire was developed in English language and used to collect information on beef cattle housing and handling techniques, socio-cultural characteristics of all the stakeholders. Where a producer did not understand English, vernacular languages were used.
Data generated from the survey were subjected to descriptive statistics such as frequency distribution, percentages to explain beef cattle housing and handling techniques and the socio-cultural characteristics of all the stakeholders in the study area.

\section{Results and discussion}

Socio-cultural characteristics of beef producers in Mubi

Table 1 highlights the socio-cultural characteristics of beef producers in Mubi, Adamawa State, Nigeria.

\section{Age distribution of beef producers}

Table 1 presents the results of beef producers based on age group which indicates that, seventy five percent $(75 \%)$ are between the ages of 20 and 50 years, while twenty five percent $(25 \%)$ fall within the age group of 51 years and above. This implied that youths are more engaged in the 


\section{Beef cattle housing and handling techniques in Mubi, Adamawa State, Nigeria}

business of beef production in the study area. This could possibly be because of the hectic and tasking nature of the business which requires enough strength characterized by a lot of brain work from the production to the end consumers.

However, the aged (51 years old and above) can also, successfully participate in beef production to earn a legitimate living with a little assistance from the young people. The results of this study agreed with the report of FAO (1990) that younger people are more actively involved in the cattle business in Africa.

Table 1: Socio-cultural characteristics of beef producers in Mubi

\begin{tabular}{llr}
\hline Parameter & Frequency & Percentage (\%) \\
\hline Age distribution (in years) & & 75 \\
$20-50$ & 75 & 25 \\
51 - above & 25 & 95 \\
Sex distribution & 95 & 5 \\
Male & 5 & \\
Female & & 85 \\
Marital status & 85 & 10 \\
Married & 10 & 5 \\
Single & 5 & \\
Divorced & 10 & 10 \\
Qualifications & 90 & 90 \\
W/Education & & \\
Nomadic/Arabic & 85 & 85 \\
Experience & 15 & 15 \\
$5-15$ & & \\
16-above & 95 & 95 \\
Tribal distribution & 5 & 5 \\
Hausa/Fulani & & 85 \\
Others & 85 & 10 \\
Religious affiliations & 10 & 5 \\
Islam & 5 & \\
Christianity & & \\
Traditional & &
\end{tabular}

The results also corroborated that of Mafimisebi et al. (2013) who reported similar findings of 41 to 50 years old as major age bracket of beef producers in Akure, Ondo State, Nigeria. This means that, majority of the beef cattle producers in Nigeria are still young and are within the active working class. This is however expected to influence their productivity and efficiency in the rigorous and energy sapping beef production business.

Sex distribution of beef producers

About ninety-five percent (95\%) of beef producers in the study area are male, while only five percent $(5 \%)$ are female. This could be because beef production business in Africa and Nigeria in particular involves physical activities like struggling and wrestling to control the cattle using sticks and robes. The business is full of risk and hazards as some animals are wild and dangerous. In addition, the Northern Muslims, which form the largest population of the beef producers, do not allow their wives to go out for such hard business, as reported by Auwal (2005).

It was additionally observed that, all beef producers had to watch their backs in case of attack as they walk and meander amongst the animals tethered to begs, with others roaming about freely. It was also gathered that, people have been killed in the past by 


\section{Kubkomawa, Kenneth-Chukwu, Krumah, Yerima, Audu and Nafarnda}

some sharp-pointed horned wild and temperamental animals. Apart from the risk of been hurt by the animals, there is also fear of armed robbers striking the production sites at any time since no security agents are physically seen around to scare armed robbers away. Some producers use charms to enable them manoeuvre their ways easily within the production sites without any challenge from the animals. Others use charms to make animals docile and easy to handle and for protection against theft and intimidation from rivals. To ensure that the beef business thrives and grow in capacity, beef production is usually ritualized. Producers also confirmed that, during the dry season the production sites used to be dusty and smoky. During the rainy seasons, it is also dirty with waters mixed with cattle feces and left over feeds forcing producers and marketers to use rain boots and coats. All these operations are too tasking and tedious for women to bear in the study area. Generally, men have the highest percentage of cattle business holdings because they are the bread winners, having reservoir of wealth and taking the responsibility of managing herds to sustain the family's livelihood. However, women and children although relegated to the background, also control portions of the livestock holdings to support the family. Iro (1994) reported that cattle belong to individual family members and are usually managed and sold together with male family members assuming automatic rights to all cattle, making it difficult to determine cattle ownership by female family members. Swinton (1987) however, reported that women own most of the small ruminants and almost all of the poultry flocks.

\section{Marital status of beef producers}

Eighty five percent $(85 \%)$ of the beef producers in the study area were married, ten percent $(10 \%)$ single, while five percent $(5 \%)$ were divorced. This shows that most of the beef producers are responsible
Nigerians doing their lawful business to earn a living and support families. It also implies that, beef production business is a profitable venture and if regulated well by the agencies concerned in the study area and Nigeria as a whole, it could keep on sustaining enumerable individuals and families. The results are in agreement with similar findings obtained by Kohls and Uhls (1985).

\section{Educational qualifications of beef producers}

The results indicate that, ninety percent (90\%) had Nomadic/Arabic education, while only ten percent $10 \%$ ) had Western education. This implies that, majority of the producers lack formal education because of their tribal and religion affiliations which do not encourage Western education. Again, this low level of Western education recorded amongst the beef producers in this study may be connected to their family backgrounds especially those who were born and brought up in the rural areas and have herded before coming to settle in the city. This lack of Western education is a great set back to them and will have negative impact in the business of beef production in the study area. The results coincided with that of Mubi et al. (2012) who reported similar findings in Mubi South L.G.A., Adamawa State Nigeria. However, the results are in contrast with Wakili (1996), who reported more beef producers with Western education than those with Qur'anic education in Gombe State, Nigeria.

\section{Experience of beef producers}

All the producers had enough experiences in the business with eighty five percent $(85 \%)$ having 5 - 15 years, while fifteen percent $(15 \%)$ had 16 years and above. This also implied that, many of the producers have been in the business for a long period of time and it is a true reflection of their ages as majorities are youths. The results corroborated that of Mubi et al. (2012), who 
reported similar findings in Mubi South L.G.A., Adamawa State Nigeria.

\section{Tribal distribution of beef producers}

The results show that, ninety five percent $(95 \%)$ of beef producers in the study area are from Hausa/Fulani and Zuwa Arab tribes, while only five percent (5\%) formed the other tribes. This is because in the time past, people from other tribes considered beef production as a lazy man's business and that it is only relevant to those who herd and produce cattle. It was also observed that, Hausa-Fulani and Zuwa Arab men always try to block other tribes from knowing the secret and joining the business. The few beef producers recorded by other tribes in this study were those categories of people who don't have alternative business; otherwise they would have opted for other businesses. Most of them serve under their masters as apprentices with little or no capital of their own.

\section{Religious affiliations of beef producers}

Eighty-five percent $(85 \%)$ of the beef producers are Muslims, while ten (10\%) and five percent $(5 \%)$ are Christians and traditionalist, respectively. This is quite possible because of their tribal status which indicated that, most of them are HausaFulani and Zuwa Arab by tribe and are well known for Islamic religion.

\section{Beef cattle housing in Mubi}

The results of beef cattle housing are shown in Table 2. The findings showed that, there is no elaborate housing used by the producers not even the government institutions. This may not be unconnected with the orientation and the pastoralism nature of the environment. Most of the animals used as beef cattle are sourced from pastoralists' herds and are used to harsh weather conditions of the tropics. Other factors could be the low educational background of the producers and lack of enough capital to invest in the housing. Elaborate housing requires enough funding and technical know-how which are not available to most of the producers.

The findings again showed that, all the producers $(100 \%)$ used make shift kraals or fenced yards without roofs for the business in the study area. There were no permanent structures such as the elaborately covered buildings for the business in the area. The kraals are locally made using woods, iron bars, wire mesh, sticks and bricks. The animals were never protected from harsh weather conditions as they were kept in the open, day and night throughout the production period as shown in Figures 3 and 4 . This situation affects negatively the performance of the animals and hence reduced output.

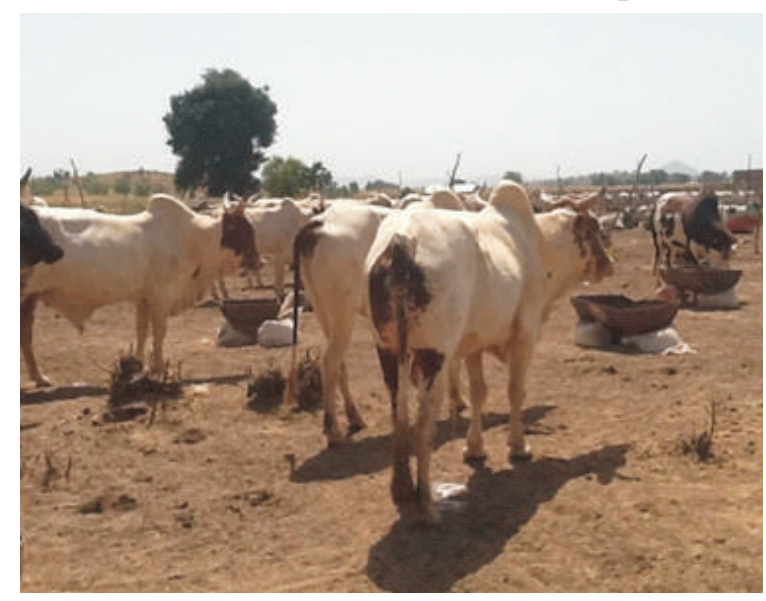

Figure 3: The use of make shift kraal (dry season) in Mubi 


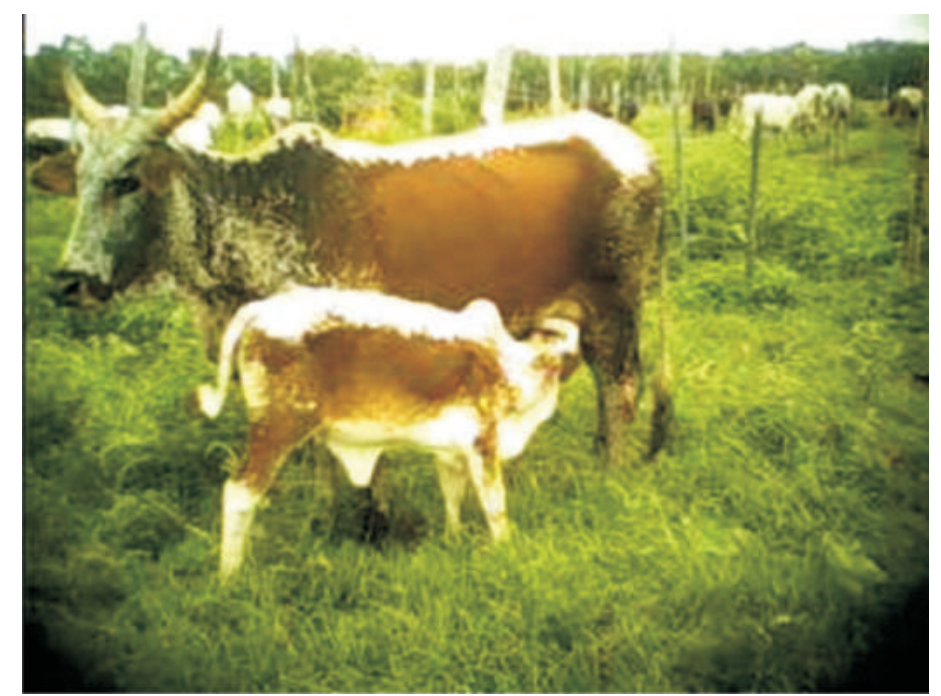

Figure 4: the use of make shift kraal (wet season) in Mubi

Table 2: Beef cattle housing and handling equipment in the study area

\begin{tabular}{llll}
\hline & Parameter & Frequency & Percentage (\%) \\
\hline A & Type of Beef Cattle Housing Used & & \\
I & Elaborate Housing & 0.00 & 0.00 \\
Ii & Make Shift Kraal & 100 & 100 \\
B & Type of Handling Equipment Used & & \\
I & Conventional Equipment & 10 & 10.00 \\
Ii & Local Equipment & 90 & 90.00 \\
\hline
\end{tabular}

\section{Beef cattle handling techniques in Mubi}

The results of handling equipment are presented in Table 2. The results showed that, $90 \%$ of the producers use locally made crush, loading ramp, grip of animals' jaws and nostrils, halter or casting.

\section{Use of crush}

The findings indicated that, producers use locally made crush or squeeze chute (a strongly built stall) for holding cattle safely as shown in Figure 5. It is used to enable easy access for examination of different sizes of animals. Crushes are used to minimize the risk of injury to both the operator and the animals. There are different types of cattle crushes with different features. Unlike the local one used in the study area, conventional crush has typical features such as push-pull lever, dual locking system, side gates (with slam gate latches), needle gates, inspection gates, bottom gate, and walk through vet compartment. The conventional crush is $5 \mathrm{~m}$ long and $0.75 \mathrm{~m}$ wide holding 2 to 3 animals at a time.

\section{Use of loading ramp}

The results also showed that, producers use locally made animal loading facilities which help to reduce loading time and the likelihood of injury to cattle and operators as shown in Figure 6. Low-bed trailers, less than 12 inches from the ground, with a drive-in alley and side gates to funnel the cattle are used.

It was gathered that, many injuries arise from loading and unloading cattle. A suitable loading ramp is essential for safe loading of trailers or trucks. All ramps had ramp gates in place; gates are strong and secured and operate freely and lock in 


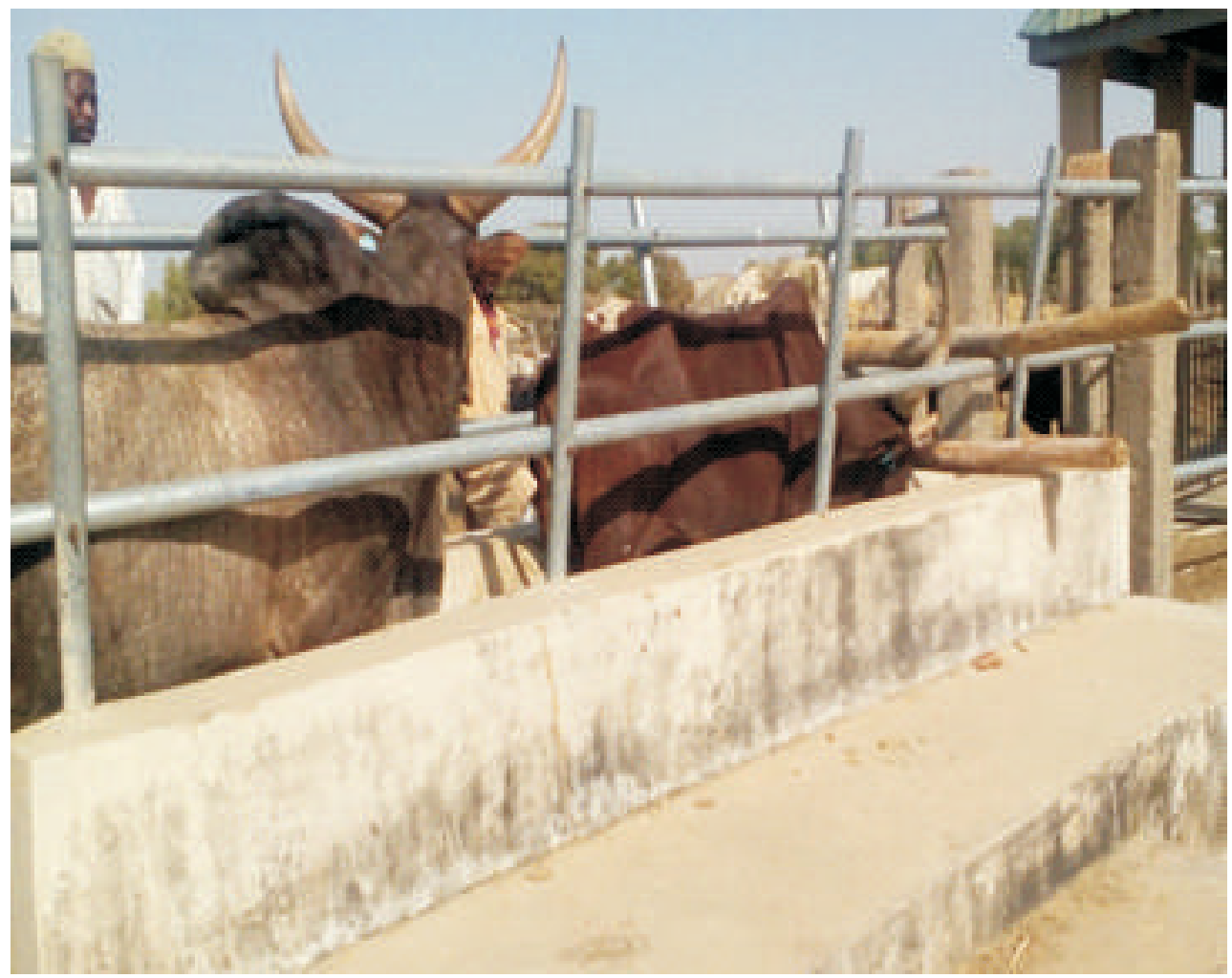

Figure 5: The use of crush in Mubi

securely when closed. The cattle generally dislike being loaded onto a trailer and understandably some will resist. The stockman is always patient and calm allowing adequate time for cattle to be loaded. The results also showed that, precaution are taken when loading and when closing up the ramp gates because a lot of accidents do occur when closing the gates as cattle can kick back or push back on top of the handler. The stockman always stands to the side when lifting the ramp and seeks assistance wherever possible so as to avoid back injury. The findings again showed that, steps provided for the cattle are less than $20 \mathrm{~cm}$ high and the ramp angle less than 15 degrees. Non-slip surfaces are provided and in some instances straw or hay are spread on the loading ramp. When the ramp is lowered to unload cattle, the stockman steps well to the side in case a stampede occurs. When unload is slow, the animals are allowed to come down on their own time. They are not rushed as they will always want to leave the trailer. The results revealed that, unloading large numbers of animals is easier with wide docks. But some trucks require wide platforms because of built-in wide unloading ramps. Combination swinging and telescoping gates are provided to close off areas between permanent loading dock sides and truck. Provision of solid sides of 5 to 6 feet high prevents distraction of animals. Provision of a catwalk on one side of the ramp is done for the operators. Provision of a 20 degrees incline with grooves or steps, 1 -foot-wide and $3 \frac{1}{2}$ to 4 inches high reduce the chance of slipping or falling. 


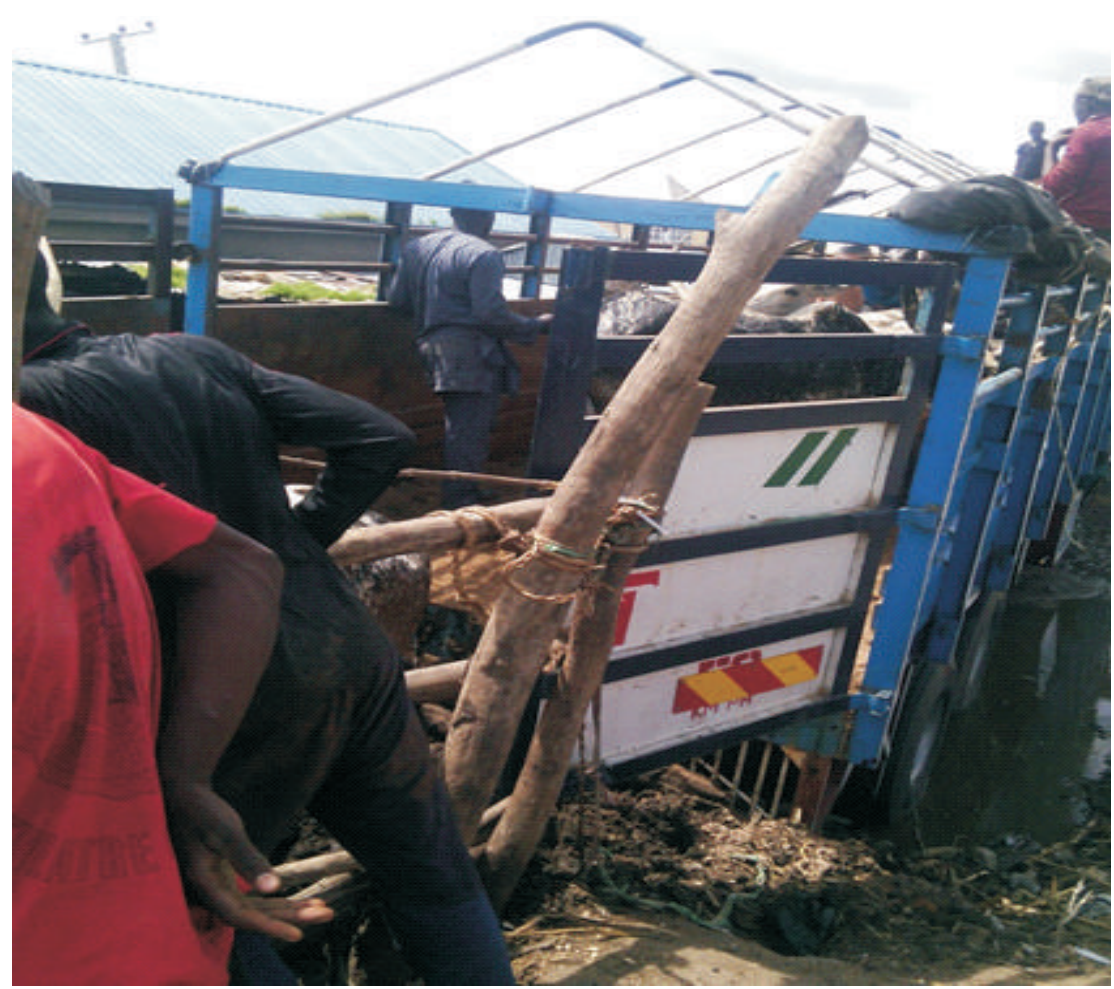

Figure 6: The use of loading ramp in Mubi

\section{Grip of animals' jaws and nostrils}

The results showed that, animals without horns or those who do not resist being held by attendants, can be handled properly by putting one's fingers in their nostrils pulling their heads closer and holding them firmly to stand still. This method is safer as the fingers exert pressure and pains to the animal thereby, surrendering fully to whatever examination or treatment meted out to it as can be seen in Figure 7. This local method of restraining animals may be cheaper but has its own short comings. As many operators do not use hand gloves, a practice that encourages disease transmission.

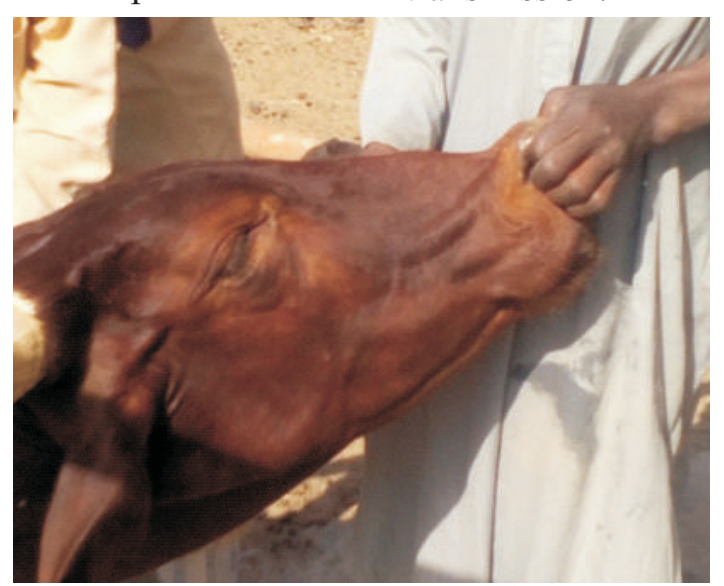

Figure 7: The use of grip of animals' jaws and nostrils in Mubi 


\section{Beef cattle housing and handling techniques in Mubi, Adamawa State, Nigeria}

\section{Use of halter or casting technique}

The results showed that, animals are restrained by holding them securely or tie them up with a halter or cast them leaving a long stick tied to the horns as shown in Figure 8. This helps to manage badtempered cattle to catch and handle them safely. Before putting on a halter, animals are stroked on their heads continuously without hesitating as cattle can sense the fear of a human. The technique is by holding the halter with the knot at a water drop position indicating the top part over the head and the lower hole to the nose piece. The operator walks toward the animal but stands outside the flight zone of the cattle to prevent the animal from panicking. The rope is placed on the head piece behind the ears of the animal and the rope of the nose piece under the mouth then adjusting the rope to fit the animal. The operator pulls the long string attached to tighten the halter. $\mathrm{He}$ circles the rope on a pole. To prevent the animal from moving its head when checking the eyes or ears, the operator pulls the rope until the animal faces one direction. The rope is tied to the crush tightly to prevent the animal from getting free.

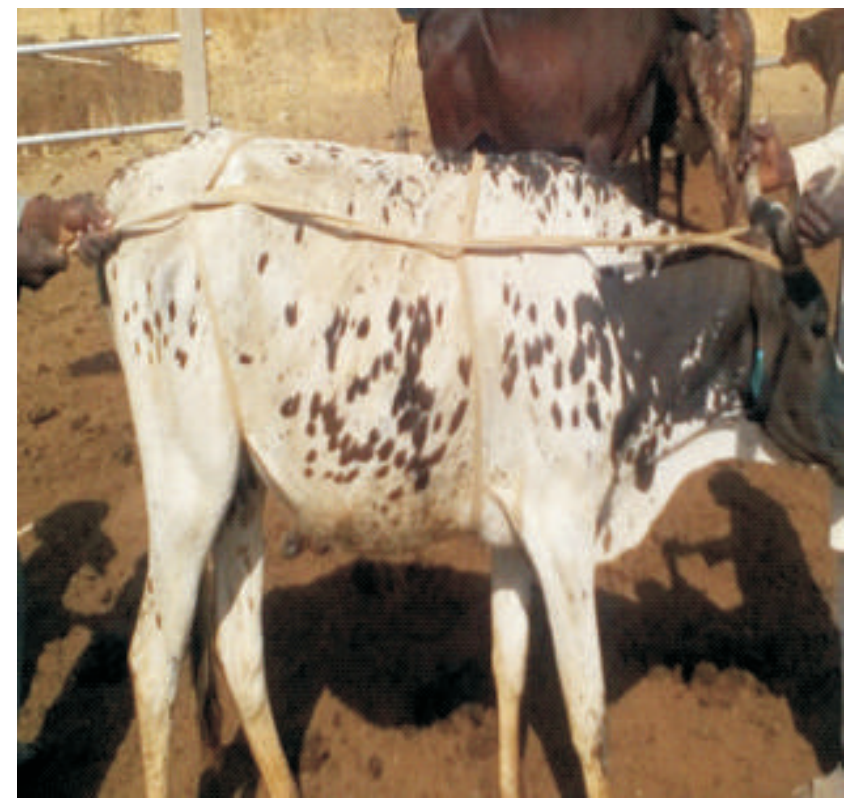

Figure 8: The Use of Halter in Mubi

The results showed that, $10 \%$ of the producers use conventional equipment in handling beef cattle in the study area. The equipment includes nose-ring and weighing bridge as shown in Figures 9, 10 and 11 .

\section{Use of nose-ring}

The findings showed that, nose-rings are used with ropes or chains attached to them to hold firmly the noses of very strong animals restraining them completely in one place. This helps the veterinary personnel to carry out any medical examination and possible treatment on the animal with ease, without fear of injury (Figures 9 and 10). 

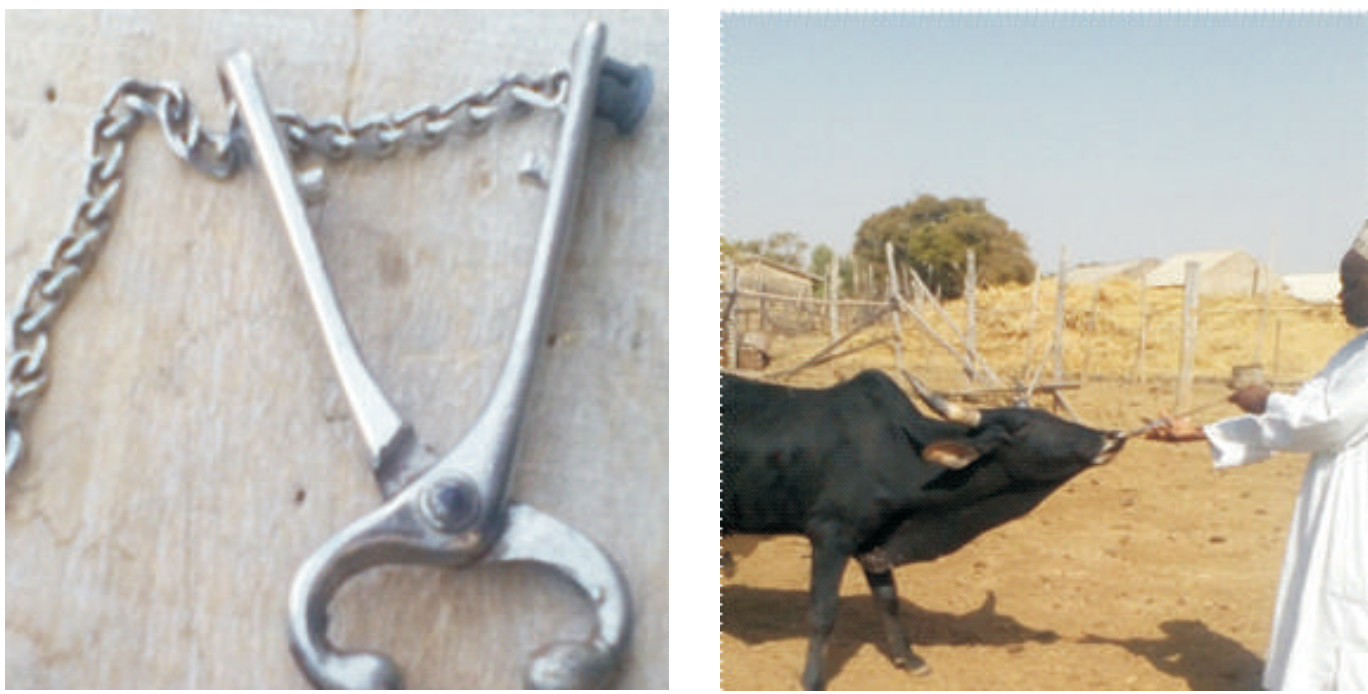

Figure 9: Nose ring

Figure 10: The use of nose-ring in Mubi

\section{Use of weighing bridge}

The results showed that, digital weighing bridges are used in the study area especially the institution based producers as shown in Figure 11. The process of weighing different classes of beef cattle at various stages is essential for the efficient management, supplementary feeding and selection of animals for fattening programme. However, it is observed that, weighing is kept to a minimum, that is when necessary, and often only a sample of each herd need to be weighed. If a sample is weighed, this should be at the same marked sample of approximately 30 herd or $10 \%$ of the herd, whichever is greater. Animals are weighed at the same time of the day under conducive atmospheric weather conditions as constant as possible.

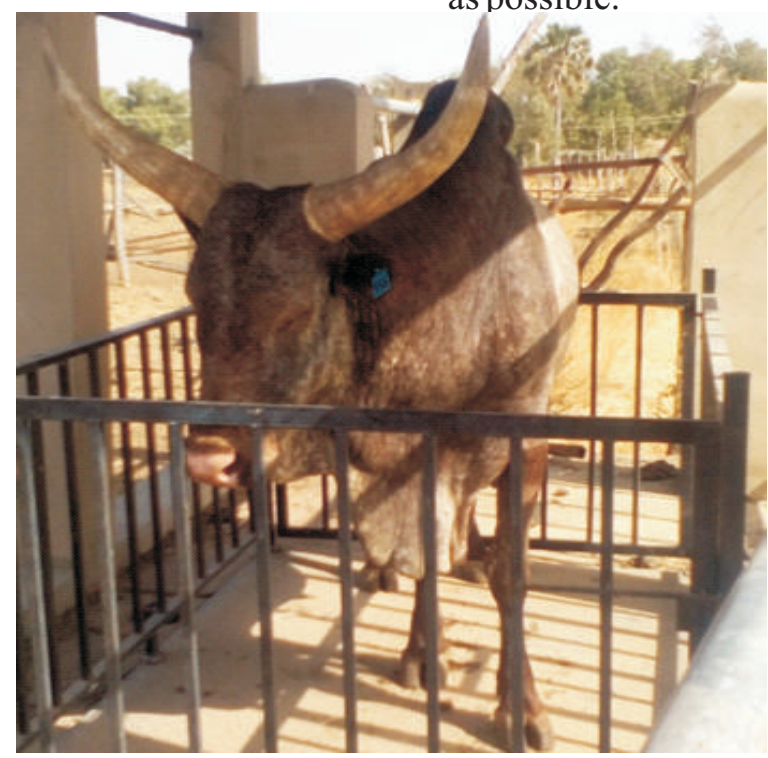

Figure 11: The use of digital weighing bridge in Mubi 


\section{Conclusion and recommendations}

It is concluded that, most beef cattle producers in the study area still use indigenous housing and handling technologies. This is contrary to modern beef production where animals are kept indoors all the year round. Therefore, whatever housing system is used, behavioural needs of animals such as resting, feeding and drinking should properly be met. Beef cattle should have access to areas, either natural or man-made, that provide relief from weather that is likely to create a serious risk to their welfare.

In addition, all beef operations should have access to equipment or facilities for the safe handling, restraint, treatment, segregation, loading and unloading of animals. This is because careful, quiet handling of cattle is also important in improving productivity. Stress imposed by handling and transportation have detrimental effects on weight gain, rumen function, reproductive function, and the immune system. Therefore quiet handling reduces stressrelated meat-quality problems such as dark cutters.

\section{References}

ADADP 1986. Adamawa Agricultural Development Programme. Method of Vegetable Gardening, pp. 3-4.

Adamu, S. M. and Kubkomawa, H. I. 2018. Beef Production and Marketing in Tropical Africa: Entrepreneurship in Animal Agriculture. First Edition Published by Tapass Institute of Scientific Research and Development Ezeogidi Estate, Umunwanio Irete, P. O. Box 2143 Owerri, Imo State, Nigeria, pp. 131-145.

Adebayo, A. A. and Tukur, A. L. 1991. Adamawa State In maps. Paraclete Publishing company Yola, Adamawa Mubi, A. A., Michika, S. A. and Midau, A.
State, Nigria, pp. 35 - 40.

Alberta, SPCA 2014. Need To Know: Housing \& Fencing Structures for $\mathrm{B}$ e e f C a t t l e . www.cps.gov.on.ca/english/framei ndex.htm.

ASMLS 2010. Map of Nigeria Showing all States. Adamawa State Ministry of Land and Survey, Yola, Nigeria.

Auwal, A. 2005. Political Decisions in Nigerian Agricultural Industry. Journal of Applied Sciences and Management, 2, 186.

FAO 1990. Production Year Book. Rome, Italy, 46, 153.

INEC 1996. Independent National Electoral Commission. Nigerian Electoral Body Responsible for Organization and Conducting General Elections.

Iro, I. S. 1994. The Fulani herding system. African Development Foundation, Washington.

Kohls, R. L. and Uhl, J. N. 1985. Marketing of Agricultural Products. Sixth Edition, McMillan Publishers Company, New York, pp. 5 - 8 .

Mafimisebi, T. E., Bobola, O. M. and Mafimisebi, O. E. 2013. Fundamentals of Cattle Marketing in Southwest, Nigeria: Analyzing Market Intermediaries, Price Formation and Yield Performance. Paper presented at the 4th International Conference of the African Association of Agricultural Economists, held in Hammamet, Tunisia from September 22-25, 2013.

Mansir, M. 2006. Livestock Marketing and Transportation in Nigeria.

Mohammed, K. 1999. Historical background. In A. A. Adebayo and A. L. Tukur (Ed) Adamawa state in maps. Paraclete Publishers, Yola. 
2012. Cattle marketing in Mubi Area of Adamawa State, Nigeria. Agric. Biol. Journal of North America, 4(3), 199 - 204.

NPC 1991. National Population Commission. Nigerian Agency Responsible for Conducting Census.

Swinton, S. 1987. Drought survival tactics of subsistence farmers in Niger. Human Ecology, 1(2), 108 - 122.
Wakili, B. A. 1986. Connection and Profit Margin of Cattle marketing in Maiduguri. Student Final Year Project. Department of Agricultural Economics and Extension. University of Maiduguri, unpublished.

Received: $20^{\text {th }}$ August, 2019 Accepted: $19^{\text {th }}$ December, 2019 